\title{
A MAGYAR NYELV A TUDOMÁNYBAN. A TERMINOLÓGIA HELYE, SZEREPE ÉS FELADATAI ${ }^{1}$
}

\section{THE HUNGARIAN LANGUAGE IN SCIENCE. THE PLACE, ROLE, AND TASKS OF TERMINOLOGY}

\author{
Fóris Ágota \\ PhD, habil., egyetemi tanár, Károli Gáspár Református Egyetem Magyar Nyelvtudományi Tanszék \\ foris.agota@kre.hu \\ foris.agota@gmail.com
}

\begin{abstract}
ÖSSZEFOGLALÁS
A tanulmány célja bemutatni a terminológia területét és módszereit, a terminológiastratégia kérdéskörét és a magyar intézményrendszerét. A terminológiai munkák kapcsán bemutatom, hogy miért nélkülözhetetlen az eredeti szakmai szövegek felhasználása, a komoly szakmai lektorálás és a (kétnyelvű) eredeti korpuszok felhasználása. Végezetül megállapítom, hogy az adatokat olyan online, nyilvános adatbázisokban érdemes közzétenni, amelyek megfelelő adatmezőket tartalmaznak.
\end{abstract}

\section{ABSTRACT}

The aim of the study is to discuss the area and methods of terminology, the field of terminology strategy and its Hungarian institutions. In relation to the terminology work, I show why it is important to use original technical texts, professional reviewing and the application of (bilingual) original corpuses. Finally, I conclude, that the data should only be published in online, public databases, which contain the appropriate data fields.

Kulcsszavak: terminológia, magyar nyelv, tudományos nyelv, szaknyelv, terminológiastratégia

Keywords: terminology, Hungarian language, language of science, LSP, terminology strategy

\footnotetext{
${ }^{1}$ Elhangzott az MTA Magyar Nyelv a Tudományban Elnöki Bizottság alakuló ülésén, 2017. október 9-én.
} 
Sokakban él az aggodalom, hogy a magyar nyelv képes-e fennmaradni a tudomány nyelveként, alkalmas maradhat-e a tudományos kommunikációra, képes-e a szakszókincse lépést tartani a rendkívül gyors tudományos haladással? Az új technológiák, eszközök, kutatási eredmények többségükben angol nyelven jelennek meg először, a nemzetközi környezetben a kutatók, fejlesztők, mérnökök és más szakemberek angol nyelven kommunikálnak egymással. Minden nyelvközösségben fontos, hogy az anyanyelvi tudományos és szakmai kommunikáció háttérfeltételei biztosítva legyenek, és ezek közé sorolható a pontos, ellenőrzött terminológia az adott nyelven. A magyarnak a tudomány nyelveként való megőrzésében fontos szerep hárul a terminológiára. A tanulmány célja bemutatni, hogy mivel foglalkozik a terminológia (elméleti és gyakorlati kérdések), milyen intézményrendszere van hazánkban, és hogyan támogatják a terminológiai adatbázisok az anyanyelvhasználatot.

\section{A TERMINOLÓGIÁRÓL}

A terminológia nem azonos a szaknyelvkutatással, különbözik a nézőpontjuk, és különböznek a vizsgálati módszereik. A szaknyelvekkel kapcsolatos vizsgálatokat általában a szociolingvisztika területéhez sorolják, mivel a szaknyelvek adott társadalmi csoportok által beszélt nyelvváltozatoknak tekinthetők. A magyar szakirodalomban a társadalmi nyelvváltozatokat szaknyelvekre és csoportnyelvekre osztják, illetve egyes szerzők a köznyelvtől eltérő nyelvváltozattípusokat mind csoportnyelveknek nevezik (a társadalmi és a területi nyelvváltozatokat is), a szaknyelveket ezek egy alcsoportjaként, foglalkozásokhoz kötődő nyelvváltozatként jellemzik. (A magyar nyelvi rétegződést bemutató modelleket Tolcsvai Nagy Gábor [2003] tekinti át részletesen.)

A szaknyelvkutatás vizsgálati módszereire jellemző, hogy kontrasztív (összehasonlító) eljáráson alapulnak, és általában a köznyelv és a vizsgált nyelvváltozattípus jellemzőit vetik össze egymással. Az etalon szerepét a köznyelv tölti be, vagyis a köznyelvi változathoz viszonyítják, azzal mérik össze a másik (szaknyelvi, csoportnyelvi) változatot.

A szociolingvisztikában, és általában a nyelvészetben, a szaknyelvek lexikai állományát szakszókincsnek (vagy szakszókészletnek) nevezik. Terminusnak gyakran a szakszavakat hívják (tehát szinonimaként használják a két szót); másutt pedig, leszükítve a fogalmat, azokat a speciális szakszavakat nevezik terminusnak, amelyek csak egyetlen szaknyelvben használatosak. Amikor a terminust egyszerúen szakszónak tekintik, és azt vizsgálják, hogy melyik nyelvváltozattípusból melyik nyelvváltozattípusba került át, honnan hova vándorolt, olyankor szokás terminologizációról (köznyelvi szó szakszóvá válik) és determinologizációról (szakszó köznyelvi szóvá válik) írni. 
A terminológia szintén a szakszókinccsel (egy vagy több nyelv szakszókészletével) foglalkozik. A terminológiai vizsgálatok onomasziológiai kiindulásúak (fogalomalapúak, fogalomközpontúak), de nem a nyelvváltozatot használó társadalmi csoport jellemzői alapján közelítenek a szaknyelvekhez, hanem fogalmi, jelentéstani, rendszertani szempontból. A terminológia kiindulása abból a szempontból kommunikációs alapú, hogy a nyelvet olyan kommunikációs rendszernek tekinti, amelynek feladata a fogalmakban absztrahált ismeretek közvetítése. Ezért a fogalmat, valamint a fogalom és a jelölö viszonyát, a jelentést állítják a kérdéskör középpontjába. A terminológiai vizsgálatokban fontos a rendszeralapú vizsgálat: minden fogalom valamilyen fogalomrendszerben létezik, az egyedi fogalmak leírása csak a teljes rendszer ismeretében, illetve figyelembevételével lehetséges - ugyanígy az egyes fogalmakat jelölő terminusok megadása és leírása csak a fogalmi és a terminológiai rendszer segítségével oldható meg. Ezért egy-egy terminológiai rendszer használatához és/vagy leírásához adott (szakmai) ismeretek birtoklására is szükség van. Ez következik abból, hogy a terminussal jelölt fogalom a dologi ismeretekböl absztrakcióval alakult ki, úgy, hogy az absztrakciós folyamat során a közös jegyek kerültek kiemelésre, az egyedi jegyek viszont a fogalom egymást követő szintjein fokozatosan elmaradtak. A terminológiai és a fogalmi rendszer pontos elkülönítését és leírását az ontoterminológiának nevezett irányzat fejlesztette magas szintre (Roche et al., 2009).

A terminológiában a terminológiai munkák szükségességét általában a szakmai kommunikáció megkönnyítésével indokolják, a terminust pedig pragmatikai-kommunikatív egységnek, jelentésegységnek, ismeretalakzatnak tekintik. Morfológiailag olyan, heterogén összetételü elemeket nevezünk terminusnak, amelyek pragmatikailag hasonló funkciót töltenek be a szakmai kommunikációban.

Egyes tudományágak és szakmák fogalmi rendszere nagyobbrészt nemzetközinek tekinthető, ennek megfelelően alakult ki a terminológiai struktúrájuk is (például: természettudományok, a matematika egyes részei). Más szakterületek, mint például a jog vagy a közigazgatás fogalmi és terminológiai rendszere országhatárokkal behatárolt, országos szintü. Vannak olyan szakterületek, amelyek fogalmi rendszere nem tisztázott teljesen, és a terminológiai rendszerük nem vagy csak részben épült ki. A terminológiai munkák fő feladata a fogalmi és terminológiai rendszerek leírása, a fogalmak jellemzőinek megadása (általában jelentésmegadás definíció segítségével, és a jelentésviszonyok leírása egy adott doménen belül), valamint a terminusok nyelvi és pragmatikai jellemzőinek megállapítása és lejegyzése. Főszerepet kapnak tehát a terminológiai munkában a denotátumok, és másodlagossá válnak a nyelvi jelek. Ebben a vonatkozásban a terminológia szoros kapcsolatot mutat a számítógépes ontológiával, amely a fogalmakat szintén kapcsolatrendszereikben értelmezi, és feladatának tekinti a kapcsolatokra vonatkozó 
azon információk megadását, amelyekbe az ontológiai rendezés meghatározott szabályai szerint azok tartoznak.

A terminológiának többféle ága keletkezett, és ennek megfelelően többféle megközelítés és módszer létezik, például a Wüster-féle hagyományos (a szabványosításhoz közel álló) terminológiatan (Wüster, 1979), a Cabré-féle fordításorientált terminológiai harmonizáció (Cabré, 1998), a 2000-es évek jelentős irányzata, a szociokognitív terminológia (Temmerman, 2000), valamint az ontoterminológia (Roche et al., 2009).

A köznyelvi szókincs lejegyzését, összegyüjtését a köznyelvi (általános nyelvi) szótárakban találjuk, ezzel a lexikográfia foglalkozik. A speciális nyelvi szókincs gyűjteményeit szakszótárakban, terminológiai szótárakban és terminológiai adatbázisokban találjuk, ezzel a szaklexikográfia és a terminológia foglalkozik. Kicsit leegyszerüsítve: a lexikográfia azt keresi, mi a szóalakhoz kapcsolódó jelentés (vagyis célja a címszó leírása, különféle nyelvtani és jelentéssel kapcsolatos információk megadása); a terminológia pedig azt keresi, hogy a fogalom micsoda (milyen főbb jellemzői vannak, a jelentését és más terminusokhoz való viszonyát hogyan lehet megfelelően megadni, vagyis cél a denotátumok leírása), és hogy milyen megnevezések kapcsolódnak hozzá (amelyek segítségével a szövegekben megtalálhatóvá válik).

A müszaki szabványosításban fontos az, hogy először a fogalmakat szabványosítsák, ezt pedig úgy lehet megtenni, ha definiálják őket. Így lehet egyben nyelvfüggetlenné is tenni fogalmi rendszereket: ha a definíció minden egyes nyelvben érvényes, akkor a hozzá rendelt szóalak csak ,puszta cédula”, amely a fogalom egyértelmü jelölésére szolgál. Ha egy adott tárgykör minden fogalmát szabványosítanák, a fogalmak monoszémek lennének, és nem létezne szinonímia, akkor az így megírt szövegek könnyen fordíthatók lennének. A müszaki szabványosításban erre törekednek (hagyományosan ezt a normatív típusú terminológiatant kötjük Eugen Wüster [1979] nevéhez), de a valós nyelvhasználat nem így müködik. Azért is lényeges ezt hangsúlyozni, mert él még az a téves elképzelés, hogy szakszövegeket azért „könnyü” fordítani, mert „,egy az egyben” megfeleltetésekkel adhatók meg a terminusok a különböző nyelveken. Holott a valóságban a szakszövegekben elöforduló terminusok fordítása az N:N (sok a sokhoz) relációval írható le a leghatékonyabban (lásd például Demeczky, 2008).

\section{A TERMINOLÓGIASTRATÉGIÁRÓL}

A terminológiastratégia jelentősége főleg abban áll, hogy hozzájárul az információ-, tudás- és innovációs politikához és az oktatási stratégiákhoz. Eredményeként felgyorsul a lokalizáció (például fordítás és adaptálás a helyi kulturális és nyelvi normák figyelembevételével). Feladata, hogy elősegítse az információhoz 
való hozzájutást, elsősorban az információk közzétételével, továbbá hozzájárul a tudásmenedzsmenthez. A legtöbb nyelvközösség számára fontos, hogy tagjai ne maradjanak ki a tudományos-technikai és az ipari-gazdasági fejlödést segítő információáramlásból, és hogy az anyanyelvük alkalmas legyen a tudományos és a szakmai kommunikációra (lásd még É. Kiss, 2004; Kiss, 2009).

Az anyanyelvünk meghatározza az identitásunkat, és egyben a kommunikáció és a megismerés eszköze is. Az anyanyelv használatához való joggal viszont csak akkor tud egy közösség megfelelően élni, ha adottak bizonyos háttérfeltételek, ezek egyike, hogy létezzen pontos, szabatos, ellenörzött terminológia az adott nyelven. A terminológia létrehozásának személyi feltétele, hogy nyelvészek és az egyes szakterületeken és tudományterületeken dolgozó szakemberek közösen, összehangoltan dolgozzanak. A dologi feltételek között pedig meg kell említeni a kiépült intézményi hátteret, a szükséges eszközöket, és a folyamat időigényessége miatt jelentős anyagi ráfordítást. Természetesen azt sem hagyhatjuk figyelmen kívül, hogy az adott nyelv beszélöi számának is el kell érni egy adott küszöbértéket ahhoz, hogy érdemes legyen a terminológiát létrehozni vagy tovább építeni. Ezek az erőfeszítések csak akkor hozzák meg az elvárt eredményt, ha az így kiépített terminológia széleskörüen hozzáférhetővé is válik, azaz az ellenőrzött terminológiai adatokat nyilvános adatbázisokban és ingyenes online terminológiai szótárakban teszik közzé.

Bár számos egyéni és intézményi kezdeményezés keretében folyik terminológiai tervezés, fejlesztés a magyar nyelvterületen (elsősorban korpusztervezés és korpuszfejlesztés) - mégis, hiányzik az érdekelt területekre kiterjedő, tudományos igénnyel szervezett és összehangolt magyar terminológiastratégia (lásd részletesen Fóris, 2017). Annak érdekében, hogy elinduljon a magyar terminológiastratégia megtervezése, összehangolása, 2018. március 9-én Terminológiastratégiai kihivások a magyar nyelvterületen címmel tartottunk vitaindító konferenciát (megjelenés: Fóris-Bölcskei, 2018).

\section{A TERMINOLÓGIA MAGYAR INTÉZMÉNYRENDSZERE}

Az egyik fontos kérdés a létező intézményrendszer felmérése és leírása (erről részletesen lásd Fóris, 2017), és a továbblépés megtervezése. Európában sokféle példa van elöttünk: számos országban az országgyülés alá tartozó vagy valamely minisztérium által felügyelt nyelvi/terminológiai intézet foglalkozik a terminológiai kérdésekkel, például a katalán TERMCAT, a norvég Language Council; míg más országokban a nyelvi/nyelvtudományi intézeteknek van terminológiai osztályuk (például Litvánia, Horvátország). Magyarországon az MTA Nyelvtudományi Intézetében nincs terminológiai osztály, bár a Nyelvtechnológiai és Alkalmazott Nyelvészeti Osztályon több, a terminológiához (is) kapcsolható projekt 
indult el. 2005-ben alakult meg a MaTT (a Magyar Nyelv Terminológiai Tanácsa), amely olyan tanácskozó testület, amely laza informális kapcsolatot biztosít a terminológiával foglalkozó kutatók, fordítók és ipari szakemberek között. Ide sorolhatjuk a Károli Gáspár Református Egyetem Terminológiai Kutatócsoportját (TERMIK) és a Károli Gáspár Református Egyetemen folyó terminológia mesterszakos képzést (2011-2018). A magyar terminológia intézményrendszeréhez sorolhatjuk a TERMINI Kutatóhálózatot is, az itt folyó kutatások szerteágazóak, a vizsgálatok tárgya elsődlegesen a külső régiók magyarnyelv-használata. (Nevét nem a terminológiáról, hanem a magyar nyelv „határtalanításáról” kapta.) A Magyar Nyelvstratégiai Intézet (MANYSI) a kormány tanácsadó testülete a nyelvi, nyelvpolitikai kérdésekben, maga az intézet a Miniszterelnökség irányításával működő kormányhivatal. ${ }^{2}$ Az intézet feladatai közé sorolja a magyar nyelvvel kapcsolatos stratégiai kérdések kidolgozását, a fejlesztendő területek között pedig a terminológiát és a szaknyelveket is felsorolják. A MANYSI volt a főszervezöje a már említett Terminológiastratégiai kihívások a magyar nyelvterületen konferenciának is. Viszonylag új szereplő a terminológiastratégia területén az Országos Fordító és Fordításhitelesítő Iroda (OFFI), amely állami fordítószolgálatként fontos szerepet játszik a magyar közigazgatásban, a jogszabályok fordításában és a hiteles fordításban. Megindították az IUSTerm nevü terminológiai adatbázis építését, és kiadtak egy, a terminológiai adatbázis-építést támogató szakkönyvet (Tamás, 2017).

Természetesen nem tudtam itt minden részletre és intézményre tekintettel lenni, sok minden és sok mindenki kimaradt a felsorolásból: a magyar és külföldi egyetemek magyar nyelvi tanszékein folyó, illetve a fordítóképzésekben oktató-kutató kollégák kutatásai, eredményei, a lektorátusok, nyelvi intézetek; a különböző szakmák és szakmai szervezetek (például: Magyar Szabványügyi Testület, Mérnöki Kamara) magyar nyelvi útmutatói, az általuk készített szótárak stb.

Vannak továbbá olyan folyóiratok, amelyek sokat tettek a magyar szaknyelvek megújulásáért, a magyar szaknyelvi kutatások eredményeinek közléséért: ide sorolhatjuk a magyar nyelven megjelenő nyelvészeti és alkalmazott nyelvészeti folyóiratok többségét (például: Alkalmazott Nyelvtudomány, Magyar Nyelvőr, Magyar Nyelv, Magyar Orvosi Nyelv, Magyar Terminológia).

Az mindenesetre világosan látszik, hogy ez a szerteágazó, sokféle területet lefedő intézményrendszer alkalmas lehet a munkálatok koordinálására és az eredmények közzétételére. Az egyes intézmények keresik az együttmüködés lehetőségét, számos esetben jól müködő kooperáció van közöttük, és nagyon jó eredményeket mutatnak fel együtt. Ellentmondásos azonban, hogy átfedések vannak az egyes intézetek céljai, feladatai között. Az egyetemek, kutatóintézetek számos tudományos eredménnyel, publikációval járulnak és járultak hozzá a terminológiai

22019-től feladatkörét a Magyarságkutató Intézet veszi át.

Magyar Tudomány 180(2019)3 
kutatásokhoz. Az egyesületek, tanácsok (többé-kevésbé) biztosítják a kutatók, ipari és gazdasági szakemberek rendszeres kommunikációját. A MANYSI pedig segíthet e kialakult hálózat eredményeinek a közvetítésében, szintetizálásában a kormány, a politika számára.

\section{TERMINOLÓGIAI ADATBÁZISOK}

A modern terminológiai munkák (kutatás és alkalmazás) egyik legfontosabb területe a terminográfia (terminológiamenedzsment), vagyis a nyelvészeti, fogalmi, pragmatikai információk rögzítése a terminológiai egységekről terminológiai adatbázisokban, leggyakrabban elektronikus formában. A terminológiai adatbázisok egy- vagy többnyelvü, terminológiai adatokat tartalmazó adatbázisok, a címszavak mellett vagy helyett gyakran fogalomazonosító szerepel bennük, és nemcsak nyelvi, hanem fogalmi és pragmatikai információkat is megadnak. A komplexebb tudásbázisok pedig már nemcsak adatokat, hanem ismeretelemeket és szabályrendszereket is tartalmaznak, például terminológiai gráfokat. A terminológiai adatbázisok szóközpontú és fogalomközpontú rendszerben is tárolhatják a terminusokat és a róluk megadott információkat (részletes leírását lásd az IBM terminológusának tanulmányában: Demeczky, 2008).

A mai világban a terminológiai adatbázisok nélkülözhetetlenek, fontos szerepet játszanak többek között a fordítási munkafolyamat elökészítésében és a fordítás ellenőrzésében is. A fordítókat segítő számos eszközt összefoglaló néven CAT-eszközökként emlegetik (például fordítómemóriát tartalmazó eszközök, terminológiakezelők, korpuszelemzők, szótárak, kiadványszerkesztő programok), illetve ezeknek azt a fajtáját, amely fordítómemóriát tartalmaz, forditási környezetnek hívják (részei például a fordítómemória, a terminológiakezelő, a szövegpárhuzamosító).

A terminusok szövegbeli szerepét felhasználva, többféle módszer alapján müködnek a terminuskivonatoló szoftverek, többek között a szövegbeli gyakoriság és/vagy az ortográfiai szavak együttes előfordulása alapján rendezik sorba a szövegben elöforduló lexikai egységeket, vagy más szövegbeli jellemzőket (például definiáló formák) vesznek figyelembe kigyüjtésük során. Bármelyik típusú szoftvert használja is azonban valaki, az eredmény mindig terminusjelöltek megtalálása; a valódi terminusok összegyüjtése, kiválasztása pedig minden esetben emberi tudást és munkát igényel.

A fordítóirodák éveken keresztül fordítanak ugyanabban a témában megrendelöknek úgy, hogy egyszerre, egy időben több fordító dolgozik ugyanazon az anyagon. Egyrészről tehát magánál az irodánál újabb és újabb dokumentumokat fordítanak ugyanabban a témában (például az Európai Uniós intézmények jogszabályai, melyeket minden egyes átdolgozás után újra kell[ene] fordítani a hiva- 
talos nyelvekre, vagy például autóipari cégeknél egy új modell megjelenésekor a használati utasítások, müszerkönyvek fordításai); másrészről több ezer oldalas fordítások rövid határidőre történő elkészítésekor ez a leghatékonyabb és leggyorsabb megoldás. Ilyenkor a szövegek koherenciája, terminológiai egységessége csak úgy tartható fenn, ha már előre szabályozzák a terminushasználatot úgy, hogy maga a fordítóiroda gondoskodik a terminológiai adatbázis elkészítéséröl. Ma már számos fordítástámogató rendszer (fordítási környezet) létezik, melyek általában két alapvető részből állnak: forditási memóriából (angolul translation memory, TM) és terminológiai adatbázisból (angolul terminology database, TD). A vásárló csak a keretrendszert kapja meg, a nyelvi adatokat (szövegeket, terminusokat) neki kell a rendszerbe feltölteni. A terminológiai adatbázis elkészítése, használata és naprakészen tartása egyúttal a minőségbiztosítás alapja is a fordítási munkafolyamatban.

A terminológiát egyértelmüen online, nyilvánosan hozzáférhető rendszerekben érdemes gyüjteni és közzétenni. A terminológiai adatbázisok között tartalmuk és szerkezetük alapján többféle változat is létezik, de sajnálatos módon kevés adatbázis tartalmaz magyar nyelvü adatokat. Ezek közül mindenképpen megemlítendők: az Igazságügyi Minisztérium gondozásában lévő Termin, az Európai Intézményközi Terminológiai Adatbázis (IATE), az EUROTERMBANK, a SAPTerm, a DictionELI Lézerterminológiai szótár (lásd Fóris, 2018); továbbá az OFFI Zrt. által gondozott jogi és közigazgatási terminológiai adatbázis (IUSTerm) és a LEG Zrt. autóipari fordítói terminológiai adatbázisa (utóbbi kettő nem nyilvános).

Az online terminológiai adatbázisok céljuktól függően készülhetnek leíró vagy előíró jelleggel, ezáltal előmozdítva a nyelv- és terminológiapolitika által meghatározott stratégiákat.

A nyilvános terminológiai adatbázisok készítéséhez anyagi fedezet és képzett terminológusok szükségesek. Csak bízni lehet abban, hogy a megfelelö anyagi fedezetet elő lehet teremteni a munkákra; a terminológusképzés újraindítása pedig reménytelivé teszi, hogy lesz elegendő képzett terminológus az adatbázisok terminológiai adatokkal való feltöltésére (Fóris, 2017).

\section{MILYEN SÜRGETŐ FELADATAINK VANNAK?}

Tudjuk, hogy különböző bizottságok, szakmai szervezetek stb. régóta foglalkoznak terminológiai adatok összegyüjtésével, és nagy energiákat fektettek egyes szakterületek terminológiai szótárainak, szakszógyüjteményeinek létrehozásába. Ezek egy része elektronikus formában készült, esetleg online is hozzáférhetö. Jelenleg nem tudjuk pontosan, milyen terminológiai szótárak, adatbázisok készültek korábban, és melyek érhetőek el már most online, nyilvánosan. 
Érdemes volna egy olyan online felületet - terminológiai portált - létrehozni (például az MTA, a Nyelvtudományi Intézet vagy a MANYSI honlapján), ahol a szótárak, szójegyzékek, adatbázisok összegyüjtött adatai megtalálhatók volnának, és itt megadni a linket, ahol ezek elérhetők. Az volna jó, ha a felületen jó kereső müködne. Ez tünik a legegyszerübben és leggyorsabban megvalósítható feladatnak.

Egy másik lehetőség volna egy terminológiai kutatócsoport létrehozása az MTA Nyelvtudományi Intézetén belül, vagy pedig egy külön terminológiai központé. Ahogy azt a 3. pontban írtam már, az intézeten belül jelenleg nincs kifejezetten a terminológiával foglalkozó osztály vagy csoport. Értékes eredményeket hozhatna az egyes szaknyelvek állapotára vonatkozó tanulmányok összegyüjtése és kiértékelése; terminológiastratégia elkészítése, stratégiai területek meghatározása (tudományos igénnyel, deskriptív szemléletben); terminológiai adatbázisok felületének, adatmezőinek, szerkezetének kialakítása, ingyenes felület biztosítása az egyes szakterületek számára, amelynek segítségével saját terminológiai szótáraikat feltölthetnék adatokkal. A kutatócsoport szakmai segítséget, tanácsokat stb. biztosíthatna mindehhez. Nagyobb lélegzetü feladat lehetne terminológiai adatbázis(ok) készítése, szaknyelvi korpuszok létrehozása és ezek alapján a nyelvi adatok feldolgozása és közzététele (a Nyelvtechnológiai Kutatócsoporttal együttmüködve). Felmerült az is, hogy elindulhatna egy Magyar Szaknyelvi Terminológia projekt, ennek keretében pedig egy nagy magyar terminológiai adatbázis építése.

Természetesen ezek a feladatok más intézményi keretben is megvalósíthatók, de mindenképpen szükségesnek látszik a megfelelő nyelvtechnológiai háttér biztosítása.

\section{ELLENVETÉSEK - VAGYIS MIÉRT ÉS HOGYAN NE FOGLALKOZZUNK A MAGYAR TERMINOLÓGIÁVAL?}

A magyar müszaki és nyelvészhagyományban a terminológiai szemléletet gyakran azonosítják a nyelvi szabványosítás kérdéskörével, a ,magyaros kifejezésmóddal” vagy a „terminuscsinálással”. Vagyis úgy gondolják, hogy a terminológus feladata, hogy „magyar szavakat használjon”, és figyelmeztesse a szakembereket „a magyaros nyelvhasználatra”, és az idegen szavak helyett „magyar szavakat alkosson" - vagyis felügyelje a nyelvhasználatot és a szaknyelvi szabványok betartását. Különösen szakemberek (például mérnökök, orvosok) szokták szóvá tenni, hogy nyelvész létünkre túl sok ,idegen szót használunk”, és hogy ne használjunk bizonyos szavakat, mert azok nem „magyarosak”. Azonban a modern terminológiai munkát nem szabad összekeverni a „szócsinálással” és a „,nyelvvédelemmel”. A terminológia modern irányzatai elsősorban nem elöíróak (nem preskriptívek), hanem leiró (deskriptív) jellegüek. A terminológus feladata a szakmai fogalom- 
rendszer és a terminológiai rendszer felderítése, leírása, közzététele oly módon, hogy ezzel elősegítse a hatékony szakmai kommunikációt, támogassa a nem szakmabelieket a szakszövegek írása és a fordítás során, és elősegítse a képzést (a szakmai és a tudományos képzést egyaránt).

A számítógépes nyelvészettel foglalkozó kollégáktól másfajta kételyek és javaslatok érkeznek. Mi értelme van ennek az aprólékos adatgyüjtésnek, amit a terminológusok csinálnak? Ök számítógépes nyelvészeti módszerekkel gyorsan „összegereblyéznek nekünk” több ezer, több millió szót, és akkor mi válogathatunk azok közül. A terminuskivonatolás régóta létező dolog, de sajnos nem tökéletes. Van, amire alkalmas (például tolmácsok számára kulcsszavak kigyüjtése egy több ezer oldalas anyagból). Emberi munka nélkül terminológiai adatbázis készítésére viszont sajnos nem alkalmas, egyrészről azért, mert a terminológiában nagyon fontos, hogy szakmailag megbízható, hiteles forrásokból származó adatokat gyüjtsünk össze és tegyünk közzé, másrészről azért, mert a terminusokat a tartalmuk alapján különítjük el, jelenleg pedig a szemantikai elemzés még nem elég fejlett ehhez, morfológiai alapon pedig nem tudjuk őket kiválogatni. Tudjuk, hogy a számítógépes nyelvészetnek megvannak a megfelelö eszközei arra, hogy meglevő szótárakat, adatbázisokat akár sok nyelven összekapcsoljanak egymással. A gond mindig ugyanaz: hogy nem állnak rendelkezésünkre a részletes, pontos, naprakész terminológiai adatok. (Ezt nagyon jól lehetett tesztelni például az EuroTermBank projekt keretében, ahol a tesztelés során derült ki, hogy a számítógépes nyelvészeti eszközök kiválóak, az adatok azonban hiányosak.) Talán a legjobban az élővilág kategorizációjához hasonlíthatnánk ezt a folyamatot: minden egyes állatot, növényt kézbe kell venni, és le kell írni a tulajdonságaikat egy adott rendszer szerint úgy, hogy az a leírás az adott rendszerbe beilleszthető legyen; csak megbízható adatokból építhető fel egy rendszer és egy vagy több adatbázis. És pontosan tudnunk kell, milyen források alapján dolgozunk, és az adatbázisokban pontosan jelölnünk kell az adatok forrását - ebből következik az, hogy az adatbázis megbízható lesz, az adatok pedig ellenőrizhetők. A korpusznyelvészetben azért dolgoznak olyan nagy mennyiségủ adattal (például az MNSZ, a Magyar Nemzeti Szövegtár első verziója milliós, a most készülő második verziója milliárdnyi szövegszót tartalmaz), mert statisztikailag megbízhatóbbak lesznek az eredmények. Nagyszerủ volna egy szaknyelvi szövegtár létrehozása - de az nem pótolná a terminológiai adatbázisokat (ahogy az MNSZ sem helyettesíti a magyar köznyelvi szótárakat).

Miért nem a Wikipédiát töltjük fel adatokkal? Ez persze jó ötlet, de ez sem helyettesíti a terminológiai adatbázist, egyszerủen azért, mert más a céljuk, a felépítésük, és más adatmezőket tartalmaznak. Persze felhasználhatnánk a wiki szoftvert arra, hogy elindítsunk egy magyar terminológiai adatbázist - de azt a munkát is el kell valakinek végezni, annak az adatmezöit is meg kell határozni és fel kell tölteni megbízható adatokkal. 


\section{KONKLÚZIÓ}

A terminológia és a terminológiai szemlélet segíthet a szaknyelvek és a tudományos nyelvek hatékonyabb és részletesebb leírásában és az adatok nyilvános közzétételében. A nehézség mindig abban áll, hogy honnan (és milyen módszerrel) nyerjük az adatokat, hogy hitelesek-e az adatok, és hogy hol tesszük közzé őket. A hiteles információt eredeti szakmai szövegek felhasználása, komoly szakmai lektorálás, és (kétnyelvü) eredeti korpuszok terminológiai feldolgozása garantálhatja. Az adatokat pedig olyan online, nyilvános adatbázisokban érdemes közzétenni, amelyek megfelelő adatmezőket tartalmaznak.

\section{IRODALOM}

Cabré, M. T. (1998): Terminology. Theory, Methods and Applications. (Terminology and Lexicography Research and Practice I) Amsterdam-Philadelphia: John Benjamins

Demeczky J. (2008): Terminológia a szoftveriparban. Magyar Terminológia, 1, 2, 189-204. http:// www.kodolanyi.hu/MANYE/materm_2008_2.pdf

É. Kiss K. (2004): Anyanyelvünk állapotáról. Budapest: Osiris Kiadó

Fóris Á. (2017): A magyar terminológia-politikáról és stratégiáról. In: Benő A. - Gúti E. - Juhász D. et al. (szerk.): Tudományköziség és magyarságtudomány a nyelvi dimenziók tükrében. Törökbálint: Termini Egyesület, 120-128. http://mek.oszk.hu/18600/18698/

Fóris Á. (2018): Tudományos kommunikáció a lézerfizikában. A nagy energiájú, atto- és femtoszekundumos, impulzusüzemü lézerek terminológiai harmonizációja. Magyar Nyelvőr, 142, 2, 187-205. http://real.mtak.hu/88003/1/Pages\%20from\%20MagyarNyelv\%C5\%91r2018.2. Bel\%C3\%ADv-187-205.pdf

Fóris Á. - Bölcskei A. (szerk.) (2018): Terminológiastratégiai kihívások a magyar nyelvterületen. Budapest: L'Harmattan-MANYSI

Kiss J. (2009): A tudományos nyelvek, az anyanyelv és az értelmiségi elit. Magyar Tudomány, 170, 1, 67-74. http://www.matud.iif.hu/2009/09jan/13.html

Roche, Ch. - Calberg-Challot, M. - Damas, L. et al. (2009): Ontoterminology - A New Paradigm for Terminology. In: KEOD 2009 - Proceedings of the International Conference on Knowledge Engineering and Ontology Development. Funchal-Madeira, Portugal, October 6-8, 2009. 321-326. http://hal.archives-ouvertes.fr/docs/00/62/21/32/PDF/Proceedings_KEOD_ 2009 128_CR.pdf

Tamás D. M. (2017): Bevezetés a jogi terminológiába a terminológus szemüvegén át. Budapest: ELTE Eötvös Kiadó

Temmerman, R. (2000): Towards New Ways of Terminology Description. The Sociocognitive Approach. (Terminology and Lexicography Research and Practice 3) Amsterdam/Philadelphia: John Benjamins DOI: 10.5788/14-0-709, http://lexikos.journals.ac.za/pub/article/view/709

Tolcsvai Nagy G. (2003): A magyar nyelvi rétegződést bemutató modellekröl. In: Hajdú M. Keszler B. (szerk.): Köszöntö könyv Kiss Jenö 60. születésnapjára. Budapest: ELTE Magyar Nyelvtudományi és Finnugor Intézete-Magyar Nyelvtudományi Társaság, 272-277.

Wüster, E. (1979): Einführung in die Allgemeine Terminologielehre und Terminologische Lexikographie. I-II. Wien-New York 